\title{
WASTE FROM THE HARVESTING OF BUTTON MUSHROOM (Agaricus bisporus) AS A SOURCE OF NATURAL MELANIN
}

\section{ODPAD Z PRODUKCJI PIECZARKI DWUZARODNIKOWEJ (Agaricus bisporus) JAKO ŹRÓDŁO NATURALNEJ MELANINY}

Center of Bioimmobilisation and Innovative Packaging Materials, West Pomeranian University of Technology, Szczecin, Poland

\begin{abstract}
Streszczenie. Naturalne melaniny mają duży potencjał aplikacyjny w farmakologii, kosmetologii oraz żywności funkcjonalnej. W badaniach otrzymano naturalną melaninę $\mathrm{z}$ odpadu powstającego podczas produkcji pieczarki dwuzarodnikowej (Agaricus bisporus). Wykonano analizę fizykochemiczną natywnej i oczyszczonej melaniny, w tym spektroskopię UV-Vis, IR oraz Ramana. Przeprowadzono również analizę wartości składowych barwy, zawartości polifenoli oraz właściwości antyoksydacyjnych i antybakteryjnych. W wyniku przeprowadzonych analiz stwierdzono, że uzyskane barwniki były podobne do syntetycznej L-DOPA melaniny. Natywna i oczyszczona melanina była zróżnicowana pod względem budowy chemicznej, aktywności antyoksydacyjnej oraz właściwości barierowych w odniesieniu do światła. Otrzymane melaniny charakteryzowały się właściwościami przeciwbakteryjnymi względem Enterococcus faecalis i Pseudomonas aeruginosa, nie działały względem Bacillus cereus, Escherichia coli i Staphylococcus aureus. Są to pierwsze badania na temat melanin otrzymanych z odpadu powstającego przy produkcji $A$. bisporus.
\end{abstract}

Key words: melanin, Agaricus bisporus, antioxidants, antibacterial properties, UV-protection.

Słowa kluczowe: melanina, Agaricus bisporus, antyoksydanty, właściwości antybakteryjne, ochrona przed UV.

\section{INTRODUCTION}

Among edible fungi, the white button mushroom, Agaricus bisporus (J.E.Lange) Imbach holds a unique position. Sporocarps of this basidiomycete are cultivated in large quantities and used as a vegetable crop. A. bisporus is widely recognised for its nutritional, organoleptic and medicinal properties, and is highly popular with consumers (De Groot et al. 1998; Gao et al. 2014). Mushrooms contain proteins, vitamins, lipids, carbohydrates and minerals. The protein concentration in mushrooms accounts for $19-35 \%$ of their dry weight. In addition, mushrooms contain 1.1-8.2\% lipids, 4-8.1\% carbohydrates and 3-32\% fibre in their dry state. Button mushrooms are also a good source of vitamins (vitamin B complexes, niacin and foliates) as well as mineral elements (potassium, phosphorus, copper and zinc) (Coşkuner and Özdemir 2000; Xu et al. 2016).

Corresponding author - Adres do korespondencji: Łukasz Łopusiewicz, Center of Bioimmobilisation and Innovative Packaging Materials, West Pomeranian University of Technology, Szczecin, Klemensa Janickiego 35, 71-270 Szczecin, Poland, e-mail: lukasz.lopusiewicz@zut.edu.pl 
The cultivation of $A$. bisporus began in France over 200 years ago and in the last few decades mushroom production has grown to be a sizeable crop within agriculture, and expanded all over the world (De Groot et al. 1998). The production of $A$. bisporus in Poland is characterized by high dynamic development. Intensive growth in mushrooms cultivation in Poland has caused the production of these products exceed 200 thousand ton in recent years (Olewnicki and Jabłońska 2012). Poland is the main producer of $A$. bisporus in Europe and one of the biggest in the world (China is the leader) (Xu et al. 2016). This production introduces large quantities of spent mushroom waste into the natural environment that must be dealth with. The agricultural and non-agricultural use of spent mushroom waste, is possible when it is secured in a suitable manner, minimizing the risk of transmission of pests, pathogenic microorganisms and weed seeds. The substrates of spent mushroom organic matter contain sizeable amount of carbon and nitrogen, with the ratio of these elements being similar to the level of humus in mineral and biologically active soil (Kalembasa et al. 2012). According to Majchrowska-Safaryan and Tkaczuk (2013) the application of spent mushroom substrate into the soil improves its physical properties and increases the content of macro- and microelements and thus may be used as a fertilizer. Another use for the $A$. bisporus waste ways may be its processing into valuable bioactive products such as melanin.

After the cultivation process mushrooms (caps together with mid-stipes) are cut off and passed on for further processing or for sale. Stipe bases are considered waste and used together with spent mushroom substrate as fertilizer. No data on the disposal of stipe bases for other applications was found in literature. After harvesting, mushrooms lose their whiteness and become increasingly brown in appearance. This change in colour, called mushroom browning, causing a deterioration in quality, is a result of the enzymatic oxidation of the polyphenols in the fungi tissues by polyphenol oxidase to create quinones, which ultimately condense to form melanin (Coşkuner and Özdemir 2000). A. bisporus contain polyphenols which can be oxidized into melanins through two distinct mechanisms: the activation of tyrosinase (an enzyme belonging to the polyphenoloxidase family) and/or spontaneous oxidation (Jolivet et al. 1998).

In recent years there has been a revival interest in the development of natural colorants for use as food additives, and in the cosmetic and pharmaceutical industries. This has been encouraged by strong consumer demand, as synthetic colorants are frequently perceived as undesirable or harmful (Yao et al. 2012). Owing to the high toxicity of synthetic compounds, the search for new natural colorants with antiradical as well as antimicrobial properties still remains a challenge for modern science.

Melanins have been isolated from a variety of phylogenic sources: animals (Mbonyiryivuze et al. 2015; Polidori et al. 2017; Sun et al. 2017), plants (Wang et al. 2006; Kannan and Ganjewala 2009; Cuevas-Juárez et al. 2014), bacteria (Kurian et al. 2014; Laxmi et al. 2016; El-Naggar and El-Ewasy 2017) and fungi (Harki et al. 1997; Suryanarayanan et al. 2004; Ye et al. 2011; Łopusiewicz 2018). Melanins are commonly represented as black and brown pigments, high molecular weight heterogenous polymers derived from the oxidation of monophenols and the subsequent polymeryzation of intermediate o-diphenols and their resulting quinones (Solano 2014). Melanins are types of 
pigments, possessing broad biological activities including antioxidant, radioprotective, thermoregulative, chemoprotective, antitumor, anti-viral, antimicrobial, immunostimulating and anti-inflammatory. Based on these features, natural melanin has the potential to be of great value and application in the fields of pharmacology, cosmetics, and functional foods (Zhang et al. 2015). Melanins have also application in modern science including modification of polymer materials (Shanmuganathan et al. 2011; Kiran et al. 2017), synthetis of nanoparticles (Apte et al. 2013), developing of semiconducting coatings (Lee at el. 2007), optoacoustic imaging (Liopo et al. 2015), modification of coatings for packaging materials (Łopusiewicz et al. 2017a, b).

Considering the growth of interest in new sources of melanin the purpose of this study was to investigate the possible use of waste, in the form of spent button mushrooms, in the production of natural melanin.

\section{MATERIAL AND METHODS}

\section{Material}

Waste from the production of $A$. bisporus (ABW - Agaricus Bisporus Waste) in the form of stipes was obtained from a local producer in Wolsztyn (Wielkopolskie voivodeship, Poland).

\section{Chemicals}

$\mathrm{NaOH}, \mathrm{HCl}, \mathrm{AgNO}_{3}, \mathrm{H}_{2} \mathrm{O}_{2}, \mathrm{FeCl}_{3}$, acetone, ethanol, ethyl acetate, chloroform, DMSO and methanol (Chempur, Poland) were used to extract, purify and offer up a characterisation of the active substances from the ABW. ABTS and $\mathrm{KBr}$ (Sigma Aldrich) were also used in this study.

To verify the antimicrobial properties of any melanin, Mueller-Hinton broth and Mueller-Hinton agar media (Merck, Germany) were used. All media were prepared according to the Merck protocol.

\section{Analysis of ABW}

Determination of dry matter

The moisture content of ABW was determined gravimetrically. 3-6 representative stipes were dried at $105^{\circ} \mathrm{C}$ to constant weight to determine their dry matter content. After drying the residues were weighten and dry matter content was calculated (Wang et al. 2010).

\section{The polyphenolic content of ABW}

Total soluble phenolic compounds (TPC) in the ethanolic extract from the ABW were measured according to Soares et al. (2009) and Gao et al. (2014) and expressed as gallic acid equivalents. Five grams of ABW were homogenised with $20 \mathrm{ml}$ of $80 \%$ ethanol for $24 \mathrm{~h}$. The homogenised mixture was filtered, and the liquid obtained was centrifuged at $6000 \mathrm{rpm}$ for $15 \mathrm{~min} .1 \mathrm{~mL}$ of the supernatant liquid was mixed with $1 \mathrm{~mL}$ of Folin-Ciocalteu reagent and $10 \mathrm{~mL}$ of saturated solution of $\mathrm{Na}_{2} \mathrm{CO}_{3}$. This was topped up to $25 \mathrm{ml}$ with distilled water and left to settle for $30 \mathrm{~min}$. The absorbance was then read at $765 \mathrm{~nm}$. A standard curve of gallic acid $(0-1 \mathrm{mg} / \mathrm{mL})$ was used for quantification, and TPC was calculated as milligrams of gallic acid equivalents (GAE)/gram of melanin (mg GAE/g). 


\section{Melanin production process}

The isolation and purification of melanin

$500 \mathrm{~g}$ of $\mathrm{ABW}$ was first homogenised (Heidolph Brinkmann Homogenizer Silent Crusher) in $500 \mathrm{~mL}$ of distilled water, and incubated $\left(24 \mathrm{~h}, 37^{\circ} \mathrm{C}\right)$ to allow acting of tyrosinase. After incubation the homogenate mixture was adjusted to $\mathrm{pH}=10$ by $1 \mathrm{M} \mathrm{NaOH}$, and incubated $\left(24 \mathrm{~h}, 65^{\circ} \mathrm{C}\right)$ to allow spontaneous polymerization of resulting o-diphenols and quinones to form melanin. Then, the mixture was filtered, centrufiged (6000 rpm, $10 \mathrm{~min}$ ), and alkaline ABW-RM mixture was used to purify melanin.

The purification of melanin was performed as described by Harki et al. (1997) with minor modifications. Alkaline ABW-RM mixture was first adjusted to $\mathrm{pH} 2.0$ with $1 \mathrm{M} \mathrm{HCl}$ to precipitate melanin, followed by centrifugation at $6000 \mathrm{rpm}$ for $10 \mathrm{~min}$ and a pellet was collected. Then, the pellet was hydrolyzed in $6 \mathrm{M} \mathrm{HCl}\left(90^{\circ} \mathrm{C}, 2 \mathrm{~h}\right)$, centrifuged $(6000 \mathrm{rpm}$, $10 \mathrm{~min}$ ) and washed by distilled water five times to remove acid. The pellet was washed with chloroform, ethyl acetate and ethanol three times to wash away lipids and other residues. Finally, the purified melanin was dried, ground to a fine powder in a mortar and stored at $-20^{\circ} \mathrm{C}$ until testing.

\section{The physiochemical characteristics of melanins}

\section{Diagnostic tests}

Different diagnostic tests as described by Selvakumar et al. (2008) and Rajagopal et al. (2011) were conducted on the melanins isolated from ABW. The testing organic solvents included acetone, ethanol, ethyl acetate, chloroform, methanol and DMSO.

Ultraviolet-visible absorption and transmittance spectra

Melanin solutions were prepared at concentration $0.1 \mathrm{mg} / \mathrm{mL}$ and the UV-Vis absorption and transmitance spectra were measured between 200 and $800 \mathrm{~nm}$. The absorbance ratio (A300/A600) values of melanins were calculated as well (Cuevas-Juárez et al. 2014). Transmittance values were measured between 200 and $800 \mathrm{~nm}$ at $0.01,0.05,0.1,0.5$ and $1 \mathrm{mg} / \mathrm{mL}$ for ABW-RM and ABW-PM; for L-DOPA melanin 0.01, 0.05, 0.1, $1 \mathrm{mg} / \mathrm{mL}$ concentrations were measured. All spectrophotometric assays were conducted in the Thermo Scientific Evolution 220 spectrophotometer.

\section{IR spectroscopy}

The IR spectra of melanins solid samples were obtained at room temperature by attenuated total reflection with a Fourier transform infrared spectrometer (Spectrum 100, FT-IR Spectrometer, Perkin Elmer). The samples were evenly mixed with $\mathrm{KBr}$, and pressed into tablets, then, scanned at a range between $650 \mathrm{~cm}^{-1}$ and $4000 \mathrm{~cm}^{-1}\left(64\right.$ scans and $1 \mathrm{~cm}^{-1}$ resolution) (Cuevas-Juárez et al. 2014).

\section{Raman spectroscopy}

Melanin samples were analysed using a Raman station (RamanStation 400F, Perkin Elemer) with point-and-shot capability using an excitation laser source at $785 \mathrm{~nm}, 100$ micron spot size. 
The visual colour of melanins

Visual colour of melanin solutions $(0.1 \mathrm{mg} / \mathrm{mL})$ values were measured by a Konica Minolta CR-5 colorimeted with the Hunter LAB colour system. The colour values were expressed as $L^{*}$ (brightness/darkness), $a^{*}$ (redness/greenness) and $b^{*}$ (yellowness/blueness) as an averages of five measurements.

\section{Antioxidant activity (ABTS assay)}

An ABTS assay was performed according to Cuevas-Juárez et al. (2014) with minor modifications. Radical 2,2'-azino-bis(3-ethylbenzothiazoline)-6-sulphonic acid $\left(\mathrm{ABTS}^{+}\right)$was produced by mixing $7 \mathrm{mM}$ ABTS with $2.45 \mathrm{mM}$ potassium persulfate $(5 \mathrm{~mL}$ of ABTS $+5 \mathrm{~mL}$ of potassium persulphate $4.9 \mathrm{mM}$ ). The mixture was incubated in darkness at room temperature for $16 \mathrm{~h}$, diluted with $7 \mathrm{mM}$ phosphate buffer $(\mathrm{pH} \mathrm{7.4)}$ to reach an absorbance of between 1.0 and 1.2 at $734 \mathrm{~nm}$. For the ABTS assay, $50 \mu \mathrm{L}$ of melanin (RM or PM), or dissolvent as control, were mixed with $1.95 \mathrm{~mL}$ of $A B T S^{+}$solution, incubated in darkness for $10 \mathrm{~min}$ at $37^{\circ} \mathrm{C}$ and then absorbance was measured at $734 \mathrm{~nm}$ and antioxidant activity $(\% A A)$ was calculated as $\% A A=\left[\left(A_{c}-A_{m}\right) / A_{c}\right] \times 100$; where $A_{c}$ and $A_{m}$ are the absorbances for the control and melanin, respectively.

Determination of the polyphenolic content of melanins

The total phenolics of the melanins were determined by the Folin-Ciocalteu reaction according to Cuevas-Juárez et al. (2014) with minor modifications. Melanin dissolved in DMSO $(20 \mu \mathrm{l})$ was mixed with $1.58 \mathrm{ml}$ of deionized water and $100 \mu \mathrm{l}$ of the Folin-Ciocalteu reagent, stirred gently for $5 \mathrm{~min}$ and added with $300 \mu \mathrm{l}$ of saturated solution of $\mathrm{Na}_{2} \mathrm{CO}_{3}$. The mixture was allowed to stand in darkness for $30 \mathrm{~min}$ at $40^{\circ} \mathrm{C}$, the absorbance was then measured at $765 \mathrm{~nm}$.

The antibacterial activity of isolated melanins

Test microorganisms, including Bacillus cereus ATCC14579, Enterococcus faecalis ATCC29212, Escherichia coli DSMZ1576, Pseudomonas aeruginosa ATCC27853 and Staphylococcus aureus DSMZ346 were separately cultivated in Mueller-Hinton broth. The antibacterial activity was tested through a well diffusion method (Helan Sounra Rani et al. 2013). $50 \mathrm{~mL}$ of Mueller-Hinton broth was inoculated by a single bacterial strain and incubated at $37^{\circ} \mathrm{C}$ for $24 \mathrm{~h}$. Mueller-Hinton agar was autoclaved and on reaching approx. $45^{\circ} \mathrm{C}, 200 \mu \mathrm{L}$ of bacterial suspension was added to $20 \mathrm{~mL}$ of medium, vigorously vortexed and poured on $90 \mathrm{~mm}$ Petri dishes. Wells were cut out by sterile tips ( $9 \mathrm{~mm}$ diameter) in triplicate on each plate and $100 \mu \mathrm{L}$ of melanin solutions at $0.1 \mathrm{mg} / \mathrm{mL}$ in DMSO were placed in the wells. DMSO served as a control. Plates were incubated at $37^{\circ} \mathrm{C}$ for $24 \mathrm{~h}$. After incubation the inhibition zones were measured.

\section{RESULTS AND DISCUSSION}

Melanins from $A$. bisporus waste (ABW) were obtained. To the best of our knowledge this is the first report of natural melanin production from button mushroom waste. The raw 
melanin (ABW-RM) was obtained through a two-step process which consisted of an enzymatic reaction, oxidative polymerization of products in alkaline conditions and acid precipitation. Purified melanin (ABW-PM) was obtained by acid hydrolysis, repeated precipitation and purification by the use of organic solvents. Figure 1 shows the scheme of obtaining ABW-RM and ABW-PM. Melanins are insoluble in acid solution, therefore, acid hydrolysis classically used to purify them is, probably insufficient to remove all associated macromolecules. Further purification was achieved by washing the melanin with chloroform, ethyl acetate and ethanol. Since this technique removes only small quantities of macromolecules, it is necessary to repeat the process several times (Harki et al. 1997).

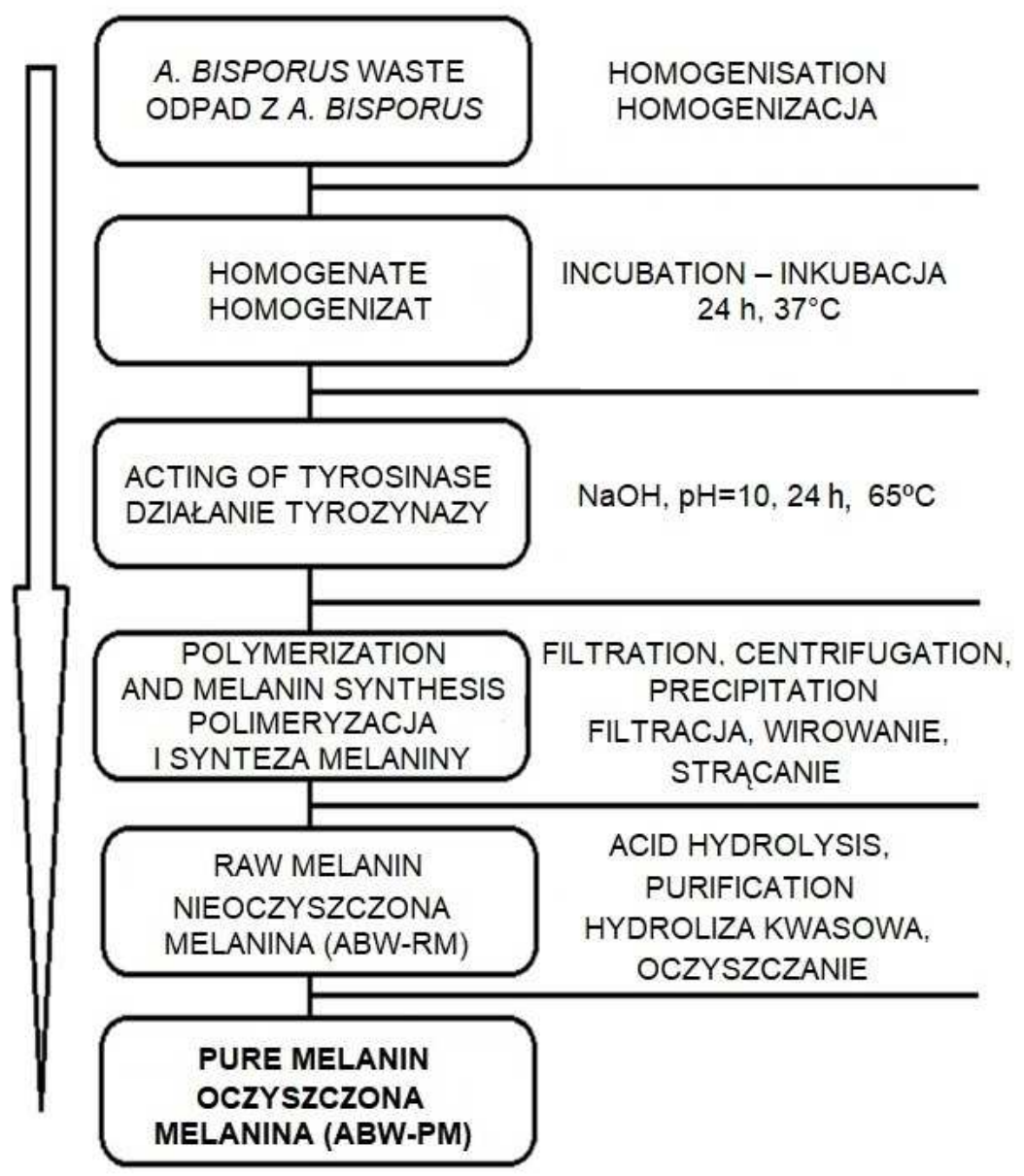

Fig. 1. The isolation and purification of melanin scheme Ryc. 1. Schemat izolacji i oczyszczania melaniny

ABW-RM was obtained based on the natural presence of tyrosinase in the fruiting bodies of $A$. bisporus. The PPO family includes catechol oxidase and laccase, both of which oxidize diphenols to corresponding quinones, but the former can also oxidize some monophenols into o-diphenols. This activity is also referred to as "phenolase” or "tyrosinase”, which has become a common name for catechol oxidase (Nerya et al. 2006). The monophenolase activity of tyrosinase is usually much lower than diphenolase activity, and this ratio, which can vary from $1: 40$ to $1: 1$ is regarded as a pivotal step in browning biosynthesis (Vamos- 
-Vigyazo 1981). Several authors have described tyrosinase activity in button mushroom fruiting bodies during their development and there is consensus that a latent form of tyrosinase occurs, though its extent is not clear. Latent tyrosinase can become active after damage, coming into contact with bacteria or a toxin such a tolaasin produced by Pseudomonas tolaasii (Soler-Rivas et al. 1997). Four pathways for natural melanin synthesis in $A$. bisporus have been proposed by Weijn et al. (2013) started from chorismate and catechol. Melanin is deposited mainly in spores. In the present research, during the first step of the process naturally occurring ABW phenolic compounds are oxidized to o-diphenols and subsequently into corresponding o-quinones. O-quinones are highly reactive compounds which may spontaneously polymerize into melanins, especially in alkaline conditions (Solano 2014).

It was noted that ABW contains polyphenolics, which may be precursors for melanin production. The total polyphenolic content in ABW was $6.22 \mathrm{mg} \mathrm{GAE} / \mathrm{g}$ of fresh stipes. The richness of phenolics in mushrooms is probably associated with a basidospore discharging function, even under circumstances of wounding/infection, since phenolics are known to act as defence substances. High phenolic content in the button mushroom is probably linked to the epigeal growth of the fruiting body. Even under circumstances serious microbial attack, the releasing function of the basidiospores produced is their main task (Rajarathnam et al. 2003). Alispahić et al. (2015) found that total phenolic content in fresh fruiting bodies of A. bisporus was $6.43 \mathrm{mg} \mathrm{GAE} / \mathrm{g}$ of fresh mushrooms. According to Palacios et al. (2011) and Muszyńska et al. (2017) A. bisporus fruiting bodies contain total phenolic compunds level of $3.5 \mathrm{mg} \mathrm{GAE} / \mathrm{g}$ of dry mushrooms and individual phenolics such as caffeic, chlorogenic, p-coumaric, ferulic, gallic, p-hydroxybenzoic, homogenistic, protocatechuic acids and catechin, myricetin and pyrogallol too, which may be pottentially polymerized into melanin.

The ABW contained $12.75 \pm 0.18 \%$ of dry mass. The extraction yield obtained for ABW was $8.24 \pm 0.13 \%$ of $A B W$ dry mass for ABW-RM and $5.19 \pm 0.24 \%$ AWB-PM after acid hydrolysis and purification. The amount of melanin in various natural sources is diverse and was reported for impure soluble melanins from fungus Inonotus obliquus $(20 \%)$ (Mazurkiewicz 2006), pure melanins from Mexican fruits (3.63-19.03\%) (Cuevas-Juárez et al. 2014), pure melanins from black tea (Sava et al. 2001), fruits and seeds of Nyctanthes arbor-tristis (0.05\%) (Kannan and Ganjewala 2009) obtained by alkaline extraction. The alkaline extraction method followed by purification through strong acid hydrolysis and washing with suitable solvents (to remove proteins and lipid residues) has been reported in literature (Harki et al. 1997; Suryanarayanan et al. 2004; Zhan et al. 2011), and is the most popular method. However, a number of other methods such as, gradient ultracentrifugation, enzymatic procedure, reprecipitation, gel filtration, adsorption on anion exchange resin, and direct rinsing with solvents without acid hydrolysis have been developed and have been noted in literature (Yao et al. 2012).

The structure of melanin polymers is little understood and an accurate definition of melanin is still required. However, the following criteria indicate melanin is: black/brown in colour, insoluble in water and most other organic solvents, resistant to degradation by hot or cold acids, bleached by oxidizing agents and solubilised by alkali solutions (Zhan et al. 2011). The ABW-RM and ABW-PM pigments presented all of the physical and chemical 
properties common to natural melanins and the experimental data within this work were found to be comparable to those reported in literature. ABW-RM and ABW-PM gave a positive reaction for polyphenols by producing flocculent brown precipitates with $\mathrm{FeCl}_{3}$, and reduced the ammonia solution of $\mathrm{AgNO}_{3}$. The results are summarized in Table 1 which also shows the properties of the L-DOPA melanin sample used for calibration. Melanins generally displayed, the same behaviour, except in the time required to bleach their alkaline solutions by the oxidizing agent used (10 min, $17 \mathrm{~min}, 19 \mathrm{~min}$, for ABW-RM, ABW-PM and L-DOPA melanin, respectively). According to Harki et al. (1997) this difference is of importance, because it depends on the type and structure of each melanin. Different reaction rates with these reagents were also obtained with L-DOPA, chatechol and DHN melanin. Melanins are commonly oxidized easly by strong oxidants such as $\mathrm{KMnO}_{4}, \mathrm{H}_{2} \mathrm{O}_{2}, \mathrm{~K}_{2} \mathrm{Cr}_{2} \mathrm{O}_{7}, \mathrm{NaOCl}$, and reduced by reducing agents such as $\mathrm{Na}_{2} \mathrm{SO}_{3}$, thus changing their chemical structures (Hung et al. 2002). In the presence of $\mathrm{H}_{2} \mathrm{O}_{2}$ the colour of ABW-RM and ABW-PM solution gradually faded, indicating that melanins were easly oxidized. Similar observations were made by $\mathrm{Ye}$ et al. (2011) using melanin isolated from Lachnum singerianum.

As shown in the Table 1 the solubility experiments indicate that ABW-RM and ABW-PM were insoluble in both water and common organic solvents (such as ethanol, chloroform, ethyl acetate, acetone). They dissolved in alkali solution and DMSO, precipitated in acidic aqueous solution $(\mathrm{pH}<3)$. The solubility of melanins was very similar to those of natural melanin previously reported, as well as synthetic melanin (Zhang et al. 2015). Lowering the $\mathrm{pH}$ of a melanin solution causes the formation of large agglomerates and melanin sedimentation. Additionaly, an increase in the $\mathrm{pH}$ value rapidly produced disaggregation into smaller sized clusters from less polymerized oligomers. This behaviour is connected to the presence of ionisable groups and hydrophobic interactions within the molecule (Prota 1992).

Table 1. Diagnostic tests for melanins

Tabela 1. Testy diagnostyczne melanin

\begin{tabular}{|c|c|c|}
\hline & \multirow[b]{2}{*}{ Test - Test } & Result - Wynik \\
\hline & & $\begin{array}{cc}\text { ABW-PM } & \begin{array}{l}\text { L-DOPA } \\
\text { melanin }\end{array} \\
\end{array}$ \\
\hline & $\begin{array}{l}\text { Solubility in water } \\
\text { Rozpuszczalność w wodzie }\end{array}$ & $\begin{array}{c}\text { insoluble } \\
\text { nierozpuszczalny }\end{array}$ \\
\hline 2. & $\begin{array}{l}\text { Solubility in organic solvents (acetone, chloroform, ethanol, ethyl } \\
\text { acetate, methanol, DMSO) } \\
\text { Rozpuszczalność w rozpuszczalnikach organicznych (aceton, } \\
\text { chloroform, etanol, octan etylu, metanol, DMSO) }\end{array}$ & $\begin{array}{l}\text { insoluble (Soluble only in DMSO) } \\
\text { nierozpuszczalny (rozpuszczalny } \\
\text { jedynie w DMSO) }\end{array}$ \\
\hline & $\begin{array}{l}\text { Solubility in } 1 \mathrm{M} \mathrm{NaOH} \\
\text { Rozpuszczalność w } 1 \mathrm{M} \mathrm{NaOH}\end{array}$ & $\begin{array}{c}\text { soluble } \\
\text { rozpuszczalny }\end{array}$ \\
\hline & $\begin{array}{l}\text { Precipitation in acidic conditions } \\
\text { Wytrącanie się w kwaśnym środowisku }\end{array}$ & $\begin{array}{l}\text { readily precipitation } \\
\text { szybka precypitacja }\end{array}$ \\
\hline & $\begin{array}{l}\text { Reaction with oxidizing agents }\left(\mathrm{H}_{2} \mathrm{O}_{2}\right) \\
\text { Reakcja z czynnikami utleniającymi }\left(\mathrm{H}_{2} \mathrm{O}_{2}\right)\end{array}$ & $\begin{array}{l}\text { decolorized } \\
\text { odbarwienie }\end{array}$ \\
\hline & $\begin{array}{l}\text { Reaction with ammoniacal } \mathrm{AgNO}_{3} \text { solution } \\
\text { Reakcja } \mathrm{z} \text { amoniakalnym roztworem } \mathrm{AgNO}_{3}\end{array}$ & $\begin{array}{l}\text { gray coloured silver precipitate on } \\
\text { tube side } \\
\text { szary osad srebra na ściankach } \\
\text { probówki }\end{array}$ \\
\hline & $\begin{array}{l}\text { Reaction for polyphenols }\left(\mathrm{FeCl}_{3} \text { test) }\right. \\
\text { Reakcja na polifenole (test } \mathrm{z} \mathrm{FeCl}_{3} \text { ) }\end{array}$ & $\begin{array}{c}\text { brown precipitate } \\
\text { brązowy osad }\end{array}$ \\
\hline & $\begin{array}{l}\text { Colour } \\
\text { Barwa }\end{array}$ & $\begin{array}{c}\text { black } \\
\text { czarna }\end{array}$ \\
\hline
\end{tabular}


Figure 2 showed ABW-RM and ABW-PM have maximum absorption peaks at $226 \mathrm{~nm}$ and $223 \mathrm{~nm}$, respectively, and exhibited an exponential decrease in the visible region. This behaviour in ABW-RM and ABW-PM were similar to the melanin synthetized from L-DOPA, used as a melanin standard. There was no absorption peak between $260-280 \mathrm{~nm}$ in the ABW-PM UV-Vis spectrum, indicating, that melanin do not contain proteins and nucleic acids. ABW-RM UV-Vis spectrum shows weak absorbtion peak in 260-280 nm region, suggesting that ABW-RM molecules may contain some amounts of linked proteins, peptides or nucleic acids (Ye et al. 2012; Łopusiewicz 2018). The UV-Vis absorption spectra of the impure (RM) and purified (PM) melanins were similar to those reported in other literature. Melanins obtained from black tea (Sava et al. 2001), plants (Wang et al. 2006), Mexican fruits (Cuevas-Juárez et al. 2014), fungi (Harki et al. 1997) and bacteria (Kurian et al. 2014) showed $\lambda_{\max }$ values in the region from 200 to $300 \mathrm{~nm}$ and lower absorption at higher wavelengths. This phenomenon is characteristic of melanins and has been associated with their complex structure, the presence of phenolic groups, as the main chromophores and the formation of complexes with compounds of low and no absorption in the visible region (Cuevas-Juárez et al. 2014). The spectral behaviour of ABW-RM and ABW-PM was very similar. Just as ABW-RM, the UV-Vis absorption spectrum of the ABW-PM melanin showed hyperchromic and bathochromic effects that could be explained by the elimination of components during the purification process. Purer melanin must induce an additive effect on chromophores characterized by a higher molar absorption (hyperchromic effect), as well as higher interactions among these chomophores (the $\lambda_{\max }$ were higher - bathochromic effect). Similar observations were obtained by Cuevas-Juárez et al. (2014) on melanin isolates from Mexican fruits.

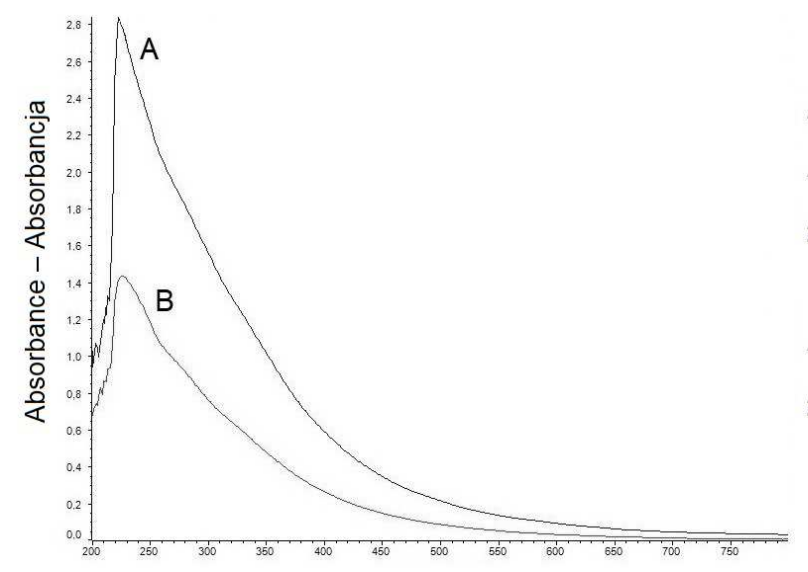

Wavelength - Długość fali [nm]

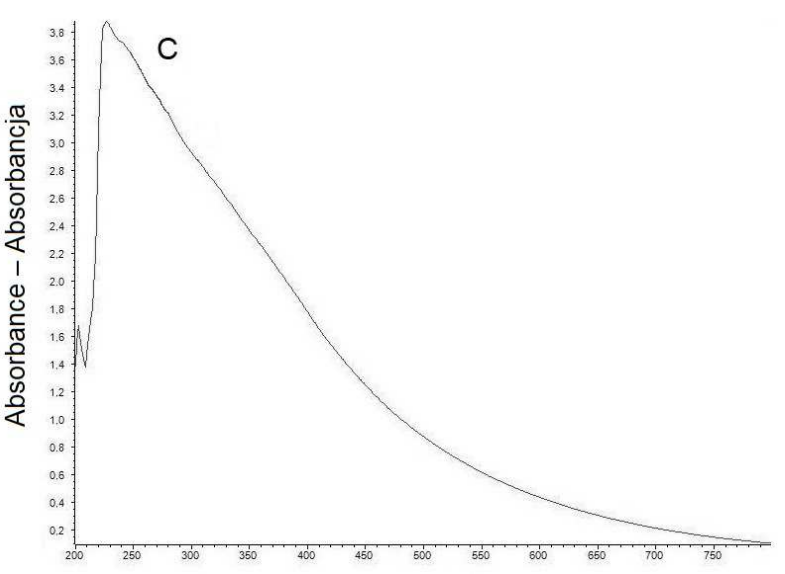

Wavelength - Długość fali [nm]

Fig. 2. The absorbance of $A B W-R M(A), A B W-P M(B)$ and L-DOPA melanin (C) Ryc. 2. Absorbancja ABW-RM (A), ABW-PM (B) i L-DOPA melaniny (C)

The broadband absorption of melanins is considered typical for organic chromophores (Meredith and Sarna 2006). Three possible explanations are given for this characteristic, featureless absorption spectrum of melanic pigments: a) that it represents a scattering phenomenon and not electronic absorption, b) that it is due to the amorphous 
semiconducting nature of the pigment, and c) that the spectrum is formed by the superposition of the spectra of many chemically different structures that make up the melanin molecule (Riesz 2007).

A decrease in absorption with increasing wavelength is almost linear in the case of melanins. Hence, the slopes of linear plots are often used to identify melanin. The log of optical density of a melanin solution when plotted against the wavelength produces a linear curve with negative slopes. Such characteristic straight lines with negative slopes have been obtained in some terrestian and marine fungi (Ravishankar et al. 1995, Suryanarayanan et al. 2004, Selvakumar et al. 2008, Zhan et al. 2011, Zhang et al. 2015). ABW-RM and ABW-PM had straight lines with negative slopes of -0.0049 and -0.0044 , respectively, indicating that the black pigments are melanins (Fig. 3).

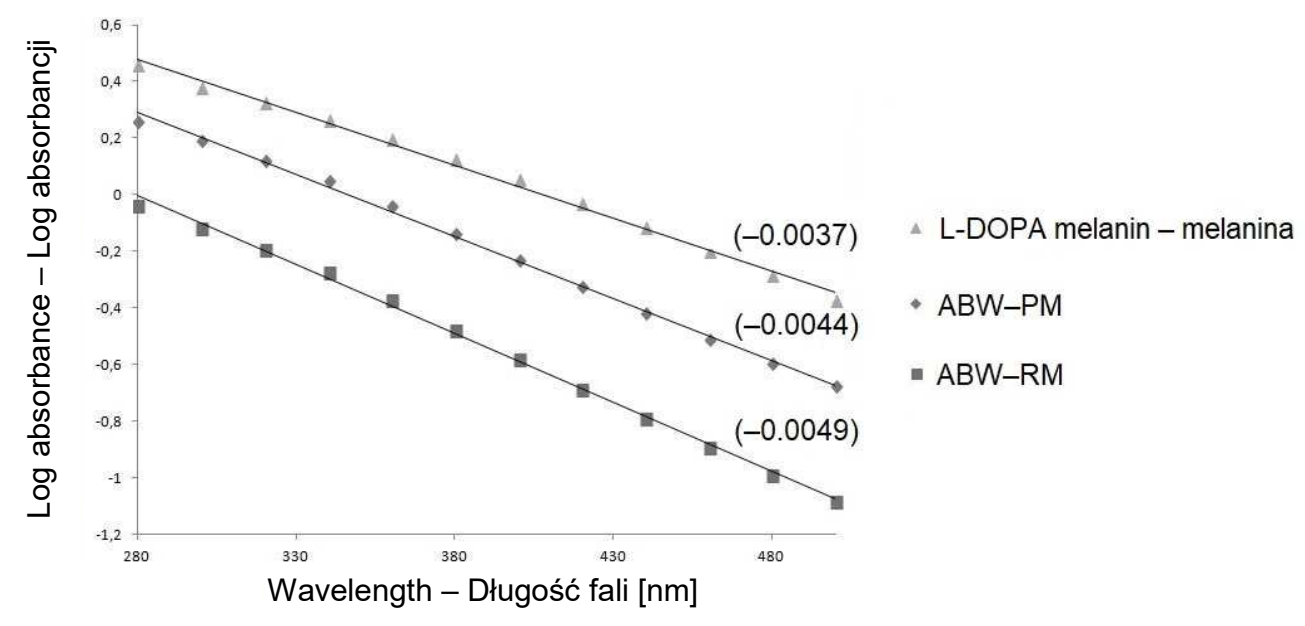

Fig. 3. A plots of log of absorbance of ABW-RM, ABW-PM and L-DOPA melanin against wavelength Ryc. 3. Wykres log absorbancji ABW-RM, ABW-PM i L-DOPA melaniny względem długości fali

The A300/A600 ratios offer information about the oxidation state and the range size of melanin molecules (Cuevas-Juárez et al. 2014). Melanin oxidation induces lower absorbance values at $600 \mathrm{~nm}(\mathrm{~A} 600)$, and the $A 300 / A 600$ absorbance ratio was proposed as a measure of the oxidation extent, high values corresponded to greater oxidized melanin molecules. Also, it was argued that during the melanin oxidation, phenolics are converted to semiquinones or quinones, which produce more oxidized (higher A300/A600 absorbance ratios) and smaller melanins (molecular weight < 1000 Da) (Haywood et al. 2006, Cuevas-Juárez et al. 2014). ABW-RM showed a higher value (26.80) than its corresponding pure ABW-PM (17.59) and L-DOPA melanin (16.00). This data supports the fact than ABW-RM are a more complex mixture of melanin molecules that that of ABW-PM, with a variability in size and degree of oxidation. These data are consistent with the results of Cuevas-Juárez et al. (2014) and also with observations made by Hung et al. (2002), who noted that oxidized and reduced melanins obtained from black tea have differences in their absorption spectra. Reduced forms of melanin have phenolic form prevalence, which when oxidized, forms show preponderance for quinone forms. Differences were also observed in the FT-IR spectra of 
oxidized and reduced melanin, showing changes in wavelengths at $3450 \mathrm{~cm}^{-1}$, this corresponding to the hydroxyl stretching vibrations that were significantly weaker in oxidized melanin (Hung et al. 2002).

The light barrier properties of ABW-RM, ABW-PM and L-DOPA melanin are shown in Fig. 4. It was noted that in all analysed concentrations, the ABW-RM transmittance values were higher than those of the corresponding ABW-PM, which suggets that in purified form, melanin has better light barrier properties, even when the transmittance values of ABW-PM were smaller than synthetic melanin.
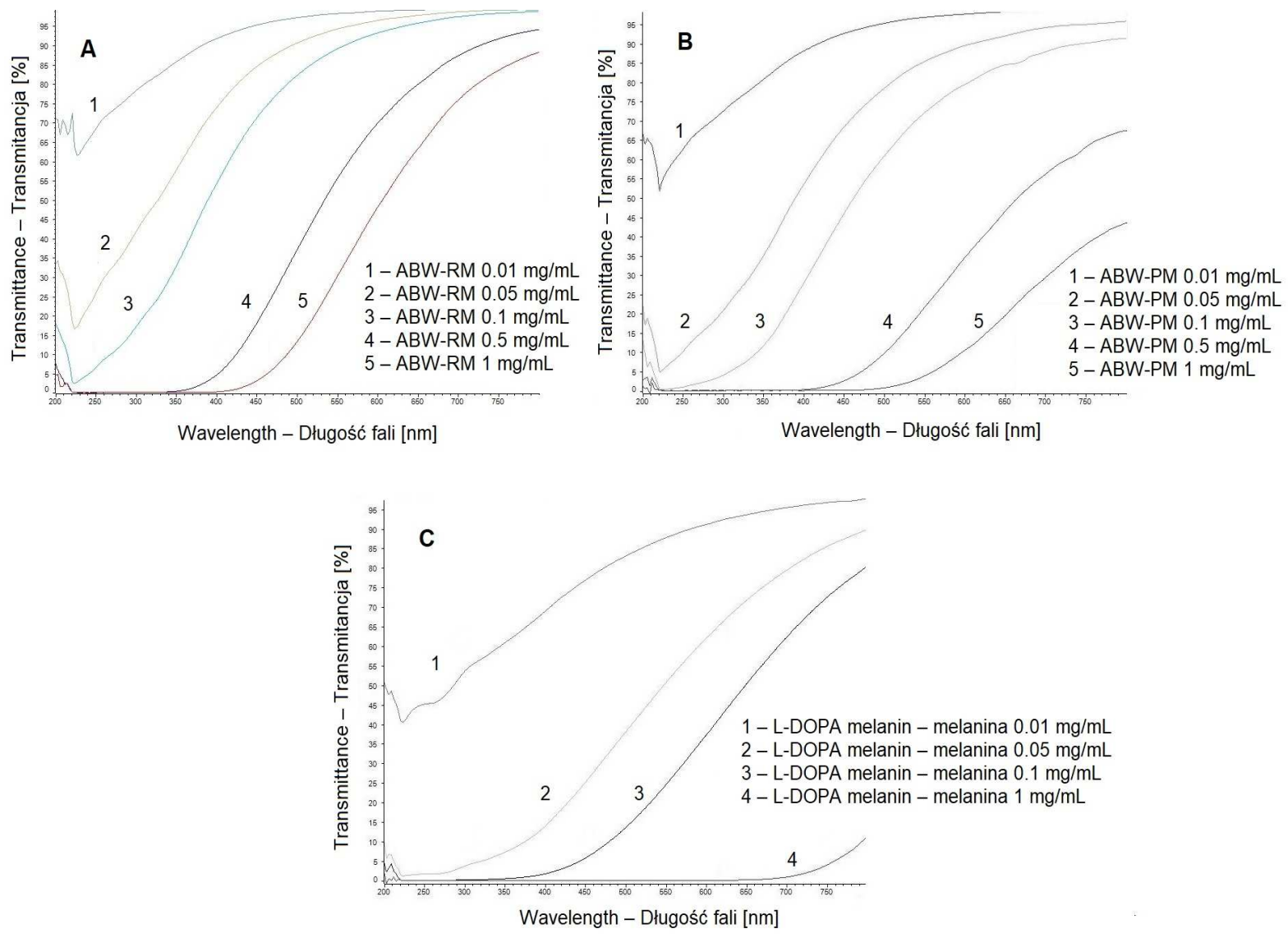

Fig. 4. Transmittance values of $A B W-R M(A), A B W-P M(B)$ and L-DOPA melanin (C) Ryc. 4. Wartości transmitancji ABW-RM (A), ABW-PM (B) i L-DOPA melaniny (C)

The colour values of ABW-RM, ABW-PM and synthetic melanin are shown in Table 2. Results from the colorimeter indicated that ABW-PM presented lower $L^{*}$ value, higher $a^{*}$ and $b^{*}$ values than ABW-RM in Hunter Lab colour system. This might be caused by the high conjugation degree of melanin which resulted in weak spectral absorbance. Similar observations were made by Zou et al. (2014). In general, melanins are dark because they do not re-radiate the absorbed visible or invisible light, but transform the energy into rotational and vibrational activity within the molecule and then dissipate it as heat. According to Nicolaus (1968), when the oxidation of diphenols such as L-DOPA, 5,6-dihydroxyindole, catechol and 1,8-dihydroxynaphtalene produce quinones with many active centres for 
polymerization, the resulting compound is generally a black pigment, whereas when the number of active centres is limited, the resulting pigment is brown, reddish-brown or yellowish-brown. Melanins with high levels of indole quinones (such as L-DOPA derived) appear darker due to the strong absorbance in the red portion of the spectrum. This low frequency light absorption is largely through carbonyls and/or oxygen-containing groups; melanins with fewer carbonyl groups are paler and appear more yellow or red (Riley 1997).

Table 2. The visual colour values of ABW-RM, ABW-PM and L-DOPA melanin Tabela 2. Wartości barwy melanin ABW-RM, ABW-PM i L-DOPA

\begin{tabular}{lccc}
\hline & $L^{*}$ & $a^{*}$ & $b^{*}$ \\
\hline ABW-RM & $95.53 \pm 0.00$ & $-0.26 \pm 0.00$ & $12.73 \pm 0.00$ \\
ABW-PM & $89.10 \pm 0.00$ & $1.52 \pm 0.00$ & $26.81 \pm 0.00$ \\
L-DOPA melanin & $74.87 \pm 0.01$ & $10.56 \pm 0.00$ & $47.74 \pm 0.01$ \\
\hline
\end{tabular}

$L^{*}$ - lightness - jasność, $a^{*}$ - green/ red - zielony/ czerwony, $b^{*}$ - blue/ yellow - niebieski/ żółty. mean - średnia $\pm S D, n=5$.

The TPC values for melanins were $0.14 \pm 0.03,0.21 \pm 0.07,0.29 \pm 0.05 \mathrm{mg} \mathrm{GAE} / \mathrm{g}$ for ABW-RM, ABW-PM and L-DOPA melanin, respectively. The TPC of ABW-PM was higher than the TPC of ABW-RM. The L-DOPA melanin showed the highest TPC value. The phenolic hydroxyl groups have a strong proton donating power. The more the hydroxyl groups are present within the melanin molecule, the more hydrogen ions are provided to combine with more active free radicals (Ye et al. 2011).

In general, the \%AA values of ABW-PM were higher than those of $A B W-R M$, and the $\% A A$ of both melanins were lower than corresponded concentrations of L-DOPA melanin as shown in Table 3. The high antioxidant activity of melanins was expected because the protection against UV-radiation and free radical scavenging are their main functions (Huang et al. 2004; Solano 2014; Cuevas-Juárez et al. 2014). The ABTS method measures both electron- and proton-transfer reactions, sensing lipophilic and hydrophilic compounds (Cuevas-Juárez et al. 2014). The ability of melanin to scavenge reactive oxygen species (ROS), such as singlet oxygen, hydroxyl radical and superoxide anion, has been firmly established in model systems, suggesting that melanin could protect pigment cells against oxidative stress that may accompany the formation of ROS in cells. Even though critical damage to oxidatively stressed cells may result from the reaction of crucial cellular constituents with ROS, an efficient antioxidant may protect the cells by scavenging other oxidizing radicals such as peroxyl radical, and by interacting with molecular oxygen (Różanowska et al. 1999). In melanins synthetized by L-DOPA oxidation, free protons found in their intermolecular spaces mediate the equilibrium between semiquinones, indolquinones, and hydroquinones forms (Goncalvez and Pombeiro-Sponchiado 2005, Cuevas-Juárez et al. 2014). It was found, that the antioxidant activity of melanin depends on its oxidative state. The possibility of melanin existing in various degrees of oxidation is one of its fundamental properties. This is caused phenol-quinine structure of melanin. However, the role of such structural peculiarities in the antioxidant activity of melanin is not clear (Hung et al. 2002). It was noted, that there was positive correlation between \%AA and TPC of analysed melanins, 
and their \%AA and TPC can be ordered as L-DOPA melanin > ABW-PM > ABW-RM. The positive correlation of the \%AA and TPC for melanins could be due to their structures. Similar observations were made by Cuevas-Juárez et al. (2014). Melanin molecules contain phenolic groups and their quantification could estimate the pigment concentration in the sample.

Table 3. The antioxidant activity (\%AA values) of ABW-RM, ABW-PM and L-DOPA melanin Tabela 3. Aktywność antyoksydacyjna (\%AA) melanin ABW-RM, ABW-PM i L-DOPA

\begin{tabular}{lclccc}
\hline $\begin{array}{c}\text { ABW-RM } \\
{[\mathrm{mg} / \mathrm{mL}]}\end{array}$ & $\begin{array}{c}\text { AA } \\
{[\%]}\end{array}$ & $\begin{array}{c}\text { ABW-PM } \\
{[\mathrm{mg} / \mathrm{mL}]}\end{array}$ & $\begin{array}{c}\text { AA } \\
{[\%]}\end{array}$ & $\begin{array}{c}\text { L-DOPA } \\
\text { melanin } \\
{[\mathrm{mg} / \mathrm{mL}]}\end{array}$ & $\begin{array}{c}\text { AA } \\
{[\%]}\end{array}$ \\
\hline 0.0625 & $0.60 \pm 0.04$ & 0.0625 & $7.18 \pm 0.32$ & 0.0625 & $20.31 \pm 0.18$ \\
0.125 & $1.45 \pm 0.05$ & 0.125 & $11.58 \pm 0.11$ & 0.125 & $31.51 \pm 0.43$ \\
0.25 & $5.39 \pm 0.15$ & 0.25 & $13.19 \pm 0.23$ & 0.25 & $50.75 \pm 0.16$ \\
0.5 & $16.76 \pm 0.13$ & 0.5 & $30.64 \pm 0.07$ & 0.5 & $95.91 \pm 0.29$ \\
1 & $48.40 \pm 0.08$ & 1 & $75.05 \pm 0.44$ & 1 & $97.16 \pm 0.03$ \\
\hline
\end{tabular}

mean - średnia $\pm S D, n=3$.

Infrared spectroscopy has been used in the chemical structure study of many melanins. It has been suggested that identical melanin structures do not exist in nature and their chemical characterization is a complicated task. Their composition depends not only on their different monomeric units, but also on enviornmental conditions during polymerization. Infrared spectrometric techniques offer information on the main functional groups in the melanin structure (Harki et al. 1997; Selvakumar et al. 2008; Zhan et al. 2011; Yao et al. 2012; Cuevas-Juárez et al. 2014; Zhang et al. 2015). A detailed comparative analysis of the infrared spectra of the melanins studied may supply valuable information on the effect of each treatment step used to purify the melanin and the distinct functional gropus prevailing in the various samples. Figure 5 shows the IR-spectra of ABW-RM, ABW-PM and L-DOPA melanin. Extra display broad absorption bands at $3600-3000 \mathrm{~cm}^{-1}$ were noted, attributed to stretching vibrations of $\mathrm{C}-\mathrm{H}, \mathrm{N}-\mathrm{H}$ and/or $\mathrm{O}-\mathrm{H}$ groups. The $\mathrm{C}-\mathrm{H}$ could be due to the presence of aromatic rings, with strong bands at $1634 \mathrm{~cm}^{-1}$ and $1629 \mathrm{~cm}^{-1}$, for ABW-RM and ABW-PM, respectively, which corresponds to the vibration of aromatic $C=C$, more intense in $A B W$ -PM. Two small peaks at $2921 \mathrm{~cm}^{-1}$ to $2851 \mathrm{~cm}^{-1}$ in both melanins may result from the oscillation of aliphatic $\mathrm{CH}_{2}$ and $\mathrm{CH}_{3}$ groups. The bands at $1228 \mathrm{~cm}^{-1}$ and $1224 \mathrm{~cm}^{-1}$ due to $\mathrm{C}-\mathrm{N}$ and $\mathrm{C}-\mathrm{O}$, would support the presence of phenols and aromatic amines. It is difficult to state whether there is an amide group, as the $\mathrm{C}=\mathrm{O}$ group that complements it might be joined in the band corresponding to aromatic $C=C$. There are differences between the ABW-RM and ABW-PM spectra which - may result from the purification process.

Figure 6 shows the Raman spectra of ABW-RM, ABW-PM and synthetic melanin. ABWRM and ABW-PM Raman spectra were similar to spectrum of L-DOPA melanin. The melanin Raman spectrum of ABW-RM is dominated by two intense and broad peaks at about $1635 \mathrm{~cm}^{-1}$ and $1248 \mathrm{~cm}^{-1}$, while ABW-PM spectrum peaks at $1620 \mathrm{~cm}^{-1}$ and $1235 \mathrm{~cm}^{-1}$ were noted. According to Huang et al. (2004) the peaks can be interrelated as originating from the in-plane stretching of the aromatic rings and the linear stretching of the $\mathrm{C}-\mathrm{C}$ bonds within the rings, along with some contributions from the $\mathrm{C}-\mathrm{H}$ vibrations in the methyl and methylene 
groups. A peak at $2000 \mathrm{~cm}^{-1}$ from both melanins is similar to those obtained by Galvan et al. (2013) from eumelanin and may be caused by the stretching of three of the six C-C bonds within the melanin rings. It was noted, that on both melanin Raman spectra peaks $\left(385 \mathrm{~cm}^{-1}\right.$ and $395 \mathrm{~cm}^{-1}$, for ABW-RM and ABW-PM, respectively) are present, which are thought to correspond to peaks obtained from pheomelanin and eumelanin and are caused by an out-of-plane deformation of phenyl rings. Peaks $2010 \mathrm{~cm}^{-1}$ and $1990 \mathrm{~cm}^{-1}$, for ABW-RM and ABW-PM, respectively, these are also similar to peaks seen in pheomelanin and are probably due to overtone or combination bands (Galván et al. 2013).

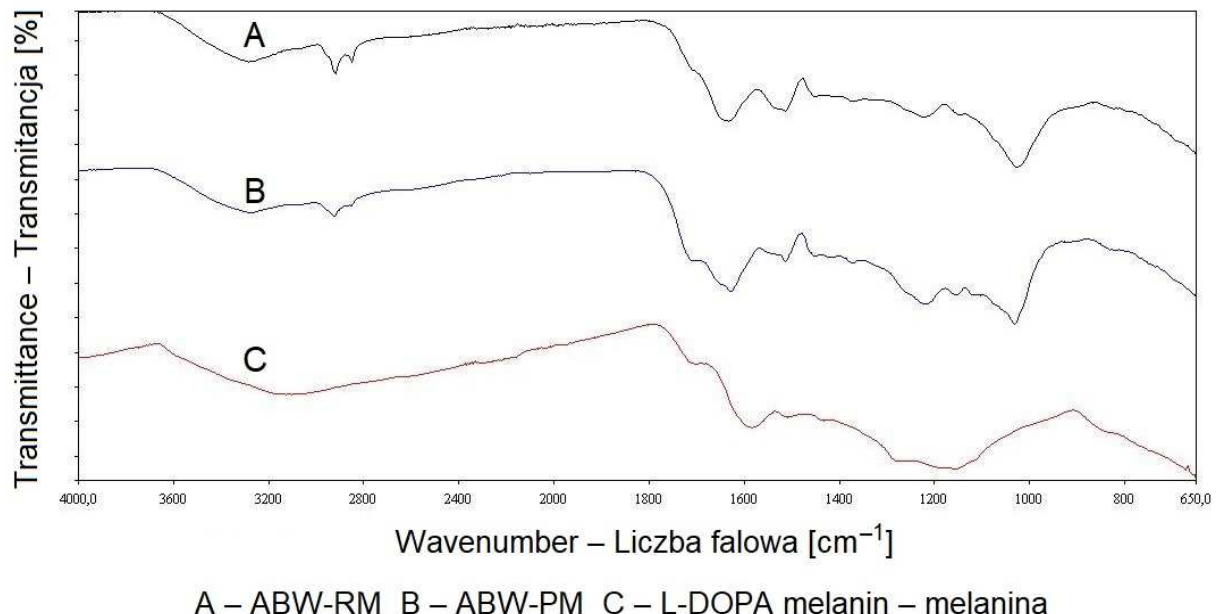

Fig. 5. Infrared spectra of L-DOPA melanin, ABW-RM and ABW-PM

Ryc. 5. Widmo FT-IR L-DOPA melaniny, ABW-RM i ABW-PM

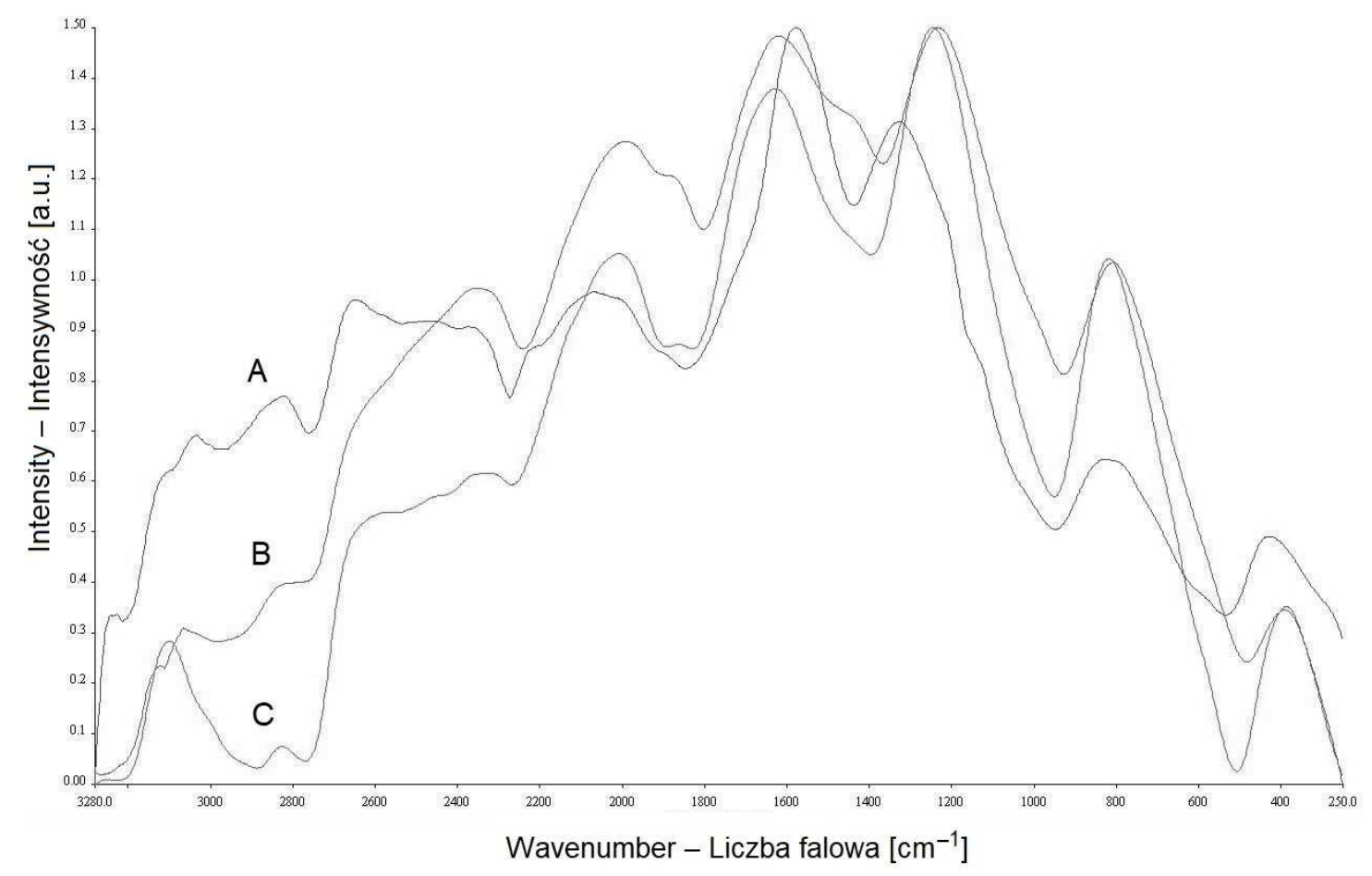

Fig. 6. Raman spectra of L-DOPA melanin (A), ABW-PM (B) and ABW-RM (C)

Ryc. 6. Widmo Ramana L-DOPA melaniny (A), ABW-PM (B) i ABW-RM (C) 
The results of an antibacterial activity assessment of ABW-RM and ABW-PM is illustrated in Table 4. The zones of growth inhibition of $E$. faecalis and $P$. aeruginosa were $12.2 \pm 0.2 \mathrm{~mm}$ and $13.7 \pm 0.1 \mathrm{~mm}$ for $A B W-R M$, respectively, while ABW-PM, were $11.3 \pm 0.1 \mathrm{~mm}$ and $12.8 \pm 0.2 \mathrm{~mm}$. No inhibition on $B$. cereus, $E$. coli and $S$. aureus was observed. Those results are supported by results of Łopusiewicz (2018), who noted similar antimicrobial activity of melanins isolated from Exidia nigricans and are partially consistent with results found by other authors. Helan Soundra Rani et al. (2013) noted antimicrobial activity of melanin isolated from halophilic black yeast Hortaea werneckii. Laxmi et al. (2016) observed that growth of $P$. aeruginosa was inhibited on the presence of melanin obtained from Providencia rettgeri, but in their study some Bacillus species were sensitive for melanin. Xu et al. (2017) analysed the antimicrobial activity of melanin from Lachnum YM30 and noted that it was active against a wide spectrum of bacteria including $S$. aureus. The authors suggest that melanin antibacterial activity might result due from damage of the cell membrane and affect the bacteria membrane function. A discrepancy in melanin antimicrobial activity may result from differences within molecule structure and composition (Correa et al. 2017). From the other hand there are some reports that melanins have antibiofilm activity agains pathogenic bacteria including $P$. aeruginosa and could interfere with bacterial quorum-sensing system, regulate its associate functions and prevent bacterial pathogenesis (Zhu et al. 2011; Bin et al. 2012; Laxmi et al. 2016; Xu et al. 2017).

Table 4. The antibacterial activity of ABW-RM, ABW-PM and L-DOPA melanin (zones of growth inhibition),

Tabela 4. Aktywność antymikrobiologiczna melanin ABW-RM, ABW-PM i L-DOPA (strefy zahamowanego wzrostu)

\begin{tabular}{lccccc}
\hline $\begin{array}{c}\text { Zones - Strefy } \\
{[\mathrm{mm}]}\end{array}$ & $\mathrm{BC}$ & $\mathrm{EC}$ & $\mathrm{EF}$ & $\mathrm{PA}$ & $\mathrm{SA}$ \\
\hline ABW-RM & - & - & $12.2 \pm 0.2$ & $13.7 \pm 0.1$ & - \\
ABW-PM & - & - & $11.3 \pm 0.1$ & $12.8 \pm 0.2$ & - \\
L-DOPA & - & - & $11.4 \pm 0.2$ & $13.1 \pm 0.1$ & - \\
melanin & - & & & & - \\
Melanina & & & & &
\end{tabular}

- no inhibition zone - brak strefy zahamowanego wzrostu, BC - B. cereus ATCC14579, EC - E. coli DSMZ1576, EF - E. faecalis ATCC29212, PA - P. aeruginosa ATCC2753, SA - S. aureus DSMZ346.

mean - średnia $\pm \mathrm{SD}, \mathrm{n}=3$.

Natural antioxidants (e.g. plant extracts) are important in the food industry to avoid oxidative reactions in diverse products (e.g. meat, poultry, emulsions, beverages and snacks) and to increase their shelf-life. Some desirable characteristics of antioxidants are the ease with they can be incorporated to diverse food matrices, heat stability, low toxicity and cost. In particular, heat stability is important in the use of such antioxidants in cooked foods (Cuevas-Juárez et al. 2014). The melanins reported in this research have the aformentioned characteristics, but non-toxicity must be corroborated in order for them to be recommended as a food additive.

\section{CONCLUSIONS}

1. The present study revealed that waste from the harvesting of button mushroom may be considered as a promising source of natural melanin. 
2. Isolated pigments presented all the physical and chemical properties common to natural and synthetic melanins.

3. Raw (ABW-RM) and purified (ABW-PM) melanins showed differences in chemical composition, antioxidant activity and light barrier properties.

4. Both melanins showed antibacterial activity against $P$. aeruginosa and $E$. faecalis. No antibacterial activity towards $B$. cereus, E. coli and $S$. aureus was observed.

\section{REFERENCES}

Alispahić A., Šapčanin A., Salihović M., Ramić E., Dedić A., Pazalja M. 2015. Phenolic content and antioxidant activity of mushroom extracts from Bosnian market. Bull. Chem. Technol. Bosnia Herzegovina 44, 5-8.

Apte M., Girme G., Bankar A., Ravikumar A., Zinjarde S. 2013. 3,4-dihydroxy-L-phenylalaninederived melanin from Yarrowia lipolytica mediates the synthesis of silver and gold nanostructures. J. Nanobiotechnol. 11(2), 1-9.

Bin L., Wei L., Xiaohong Ch., Mei J., Mingsheng D. 2012. In vitro antibiofilm activity of the melanin from Auricularia auricula, an edible jelly mushroom. Ann. Microbiol. 62(4), 1523-1530.

Correa N., Covarrubias C., Rodas P.I., Hermosilla G., Olate V.R., Valdés C., Meyer W., Magne F., Tapia C.V. 2017. Differential antifungal activity of human and cryptococcal melanins with structural discrepancies. Front. Microbiol. 8, 1-13.

Coşkuner Y., Özdemir Y. 2000. Acid and EDTA blanching effects on the essential element content of mushrooms (Agaricus bisporus). J. Sci. Food Agric. 80, 2074-2076.

Cuevas-Juárez E., Yuriar-Arredondo K.Y., Pío-León J.F., Montes-Avila J., López-Angulo G., Díaz-Camacho S.P., Delgado-Vargas F. 2014. Antioxidant and a-glucosidase inhibitory properties of soluble melanins from the fruits of Vitex mollis Kunth, Randia echinocarpa Sessé et Mociño and Crescentia alata Kunth. J. Funct. Foods 9, 78-88.

De Groot P.W., Visser J., Van Griensven L.J.L.D., Shaap P.J. 1998. Biochemical and molecular aspects of growth and fruiting of the edible mushroom Agaricus bisporus. Mycol. Res. 102(11), 1297-1308.

EI-Naggar E.-N.N., EI-Ewasy S.M. 2017. Bioproduction, characterization, anticancer and antioxidant activities of extracellular melanin pigment producet by newly isolated microbial cell factories Streptomyces glaucescens NEAE-H. Sci. Rep. 7(42129), 1-19.

Galván I., Jorge A., Ito K., Tabuchi K., Solano F., Wakamatsu K. 2013. Raman spectroscopy as non-invasive technique for quantification of melanins in feathers and hairs. Pigment Cell Melanoma Res. 26, 1-7.

Gao M., Feng L., Jiang T. 2014. Browning inhibition and quality preservation of button mushroom (Agaricus bisporus) by essential oil fumigation treatment. Food Chem. 149, 107-113.

Goncalvez R., Pombeiro-Sponchiado S.R. 2005. Antioxidant activity of the melanin pigment extracted from Aspergillus nidulans. Biol. Pharmaceut. Bull. 28, 1129-1131.

Harki E., Talou T., Dargent R. 1997. Purification, characterisation and analysis of melanin extracted from Tuber melanosporum Vitt. Food Chem. 58(1-2), 69-73.

Hayawood R. M., Lee M., Linge C. 2006. Synthetic melanin is a model for soluble natural eumelanin in UVA-photosensitised superperoxide production. J. Photochem. Photobiol. B 82, 224-235.

Helan Soundra Rani M., Ramesh T., Subramanian J., Kalaiselvam M. 2013. Production and characterization of melanin pigment from halophilic black yeast Hortaea werneckii. IJPRR 2(8), 9-17.

Huang Z., Lui H., Chen M.X.K. Alajlan A., McLean D.I., Zeng H. 2004. Raman spectroscopy of in vivo cutaneous melanin. J. Biomed. Opt. 9(6), 1198-1205. 
Hung Y.-Ch., Sava V., Makan S., Chen Tz.-H. J., Hong M.-Y., Huang G.S. 2002. Antioxidant activity of melanins derived from tea: comparision beteen different oxidative states. Food Chem. 78, 233-240.

Jolivet S., Arpin N., Wichers H.J., Pellon G. 1998. Agaricus bisporus browning. A review. Mycol. Res. 102(12),1459-1483.

Kalembasa D., Becher M., Bik B., Makolewski A. 2012. Właściwości materii organicznej podłoża po uprawie pieczarki [Organic matter properties of spent mushroom substrate]. Acta Agrophys. 19(4), 713-723. [in Polish]

Kannan P., Ganjewala D. 2009. Preliminary characterization of melanin isolated form frutis and seeds of Nyctanthes arbor-tristis. J. Sci. Res. 1(3), 655-661.

Kiran G.S., Jackson S.A., Priyadharsini S., Dobson A.D.W., Selvin J. 2017. Synthesis of Nm-PHB (nanomelanin-polyhydroxybutyrate) nanocomposite film and its protective effect against biofilm-forming multi drug resistant Staphylococcus aureus. Sci. Rep. 7(1), 9167.

Kurian N.K., Nair H.P., Bhat S.G. 2014. Melanin producing Pseudomonas stutzeri BTCZ10 from marine sediment at $96 \mathrm{~m}$ depth (Sagar Sampada cruise \#305). Int. J. Curr. Biotechnol. 2(5), 6-11.

Laxmi M., Kurian N.K., Smitha S., Bhat S.G. 2016. Melanin and bacteriocin from marine bacteria inhibit biofilms of foodborne pathogens. Indian J. Biotechnol. 15(3), 392-399.

Lee H., Dellatore S.M., Miller W.M., Messersmith P.B. 2007. Mussel-inspired surface chemistry for multifunctional coatings. Science 318, 426-430.

Liopo A., Su R., Oraevsky A. 2015. Melanin nanoparticles as a novel contrast agent for photoacoustic tomography. Photoacoustics 3, 35-43.

Łopusiewicz Ł. 2018. Isolation, characterisation and biological activity of melanin from Exidia nigricans. World Sci. News 91,11-129.

Łopusiewicz Ł., Lisiecki S., Mizielińska M. 2017a. Aktywność przeciwutleniająca folii PE i PLA modyfkowanych powłokami zawierającymi melaniny grzybowe [Antioxidant activity of polyethylene and polylactide foils modified by coating containing fungal melanins]. Opakowanie 3, 81-85. [in Polish]

Łopusiewicz Ł., Lisiecki S., Mizielińska M. 2017b. Właściwości przeciwutleniające i optyczne folii BOPP i PET modyfikowanych powłokami zawierającymi melaniny grzybowe [Antioxidant and optical properties of BOPP and PET foils modified by coatings containing fungal melanins]. Opakowanie 7, 48-56. [in Polish]

Majchrowska-Safaryan A., Tkaczuk C. 2013. Możliwość wykorzystanie podłoża po produkcji pieczarki w nawożeniu gleb jako jeden ze sposobów jego utylizacji [Possibility to uuse the spent ushroom substrate in soil fertilization as one of its disposal methods]. J. Res. Appl. Agric. Eng. 58(4), 57-62. [in Polish]

Mazurkiewicz W. 2006. Analysis of aqueous extract of Inonotus obliquus. Acta Pol. Pharm.63, 497-501.

Mbonyiryivuze A., Nuru Z.Y., Ngom B.D., Mwakikunga B., Dhlamini S.M., Park E., Maaza M. 2015. Morphological and chemical composition characterization of commercial sepia melanin. AJN 3(1), 22-27.

Meredith P., Sarna T. 2006. The physical and chemical properties of eumelanin. Pigment Cell Res. 19, 572-594.

Muszyńska B., Kała K., Rojowski J., Grzywacz A., Opoka W. 2017. Composition and biological properties of Agaricus bisporus Fruiting Bodies. A review. Pol. J. Food Nutr. Sci. 67(3), 173-181.

Nerya A., Ben-Arie R., Luzzatto T., Musa R., Khativ S., Vaya J. 2006. Prevention of Agaricus bisporus postharvest browning with tyrosinase inhibitors. Postharvest Biol.Technol.y 39, 272-277.

Nicolaus R.A. 1968. Melanins. Paris, Hermann.

Olewnicki D., Jabłońska L. 2012. Długookresowa analiza rozwoju sektora pieczarkarskiego w Polsce [Long term analysis of the mushrooms production development in Poland]. Rocz. Ekon. Rol. Roz. Obsz. Wiej. 99(4), 127-132. [in Polish] 
Palacios I., Lozano M., Moro C., D’Arrigo M., Rostagno M.A., Martínez J.A. García-Laufente A., Guillamón E., Villares A. 2011. Antioxidant properties of phenolic compounds occuring in edible mushrooms. Food Chem. 128, 674-678.

Polidori C., Jorge A., Ornosa C. 2017. Eumelanin and pheomelanin are predominant pigments in bumblebee (Apidae: Bombus) pubescence. Peer. J. 5, 1-21.

Prota G. 1992. Melanins and melanogenesis. San Diego, CA, Academic Press.

Rajagopal K., Kathiravan G., Karthikeyan S. 2011. Extraction and characterization of melanin from Phomopsis: A phellophytic fungi isolated form Azadirachta indica A. Juss. Afr. J. Microbiol. Res. 5(7), 762-766.

Rajarathnam S., Shashirekha M., Rashmi S. 2003. Biochemial changes associated with mushroom browning in Agaricus bisporus (Lange) Imbach and Pleurotus florida (Block \& Tsao). Commercial implications. J. Sci. Food Agric. 83, 1531-1537.

Ravishankar J.P., Muruganandam V., Suryanarayanan T.S. 1995. Isolation and characterization of melanin from a marine fungus. Bot. Mar. 38, 413-416.

Riesz J.J. 2007. The spectroscopic properties of melanin. PhD thesis. School of Physical Sciences, University of Queensland (typescript).

Riley P.A. 1997. Melanin. Inter. J. Biochem. Cell Biol. 29, 1235-1239.

Różanowska M., Sarna T., Land E.J. Truscott T.G. 1999. Free radical scavenging properties of melanin: interaction of eu- and pheo-melanin models with reducing and oxidizing radicals. Free Radic. Biol. Med. 26, 518-525.

Sava V.M., Yang S.-M., Hong M.-Y., Yang P.-C., Huang G.S. 2001. Isolation and characterisation of melanic pigments derived from tea and tea polyphenols. Food Chem. 73, 177-184.

Selvakumar P., Rajasekar S., Periasamy K., Raaman N. 2008. Isolation and characterization of melanin pigment from Pleurotus cystidiosus (telomorph of Antromycopsis macrocarpa). World $\mathrm{J}$. Microbiol. Biotechnol. 24, 2125-2131.

Shanmuganathan K., Cho J.H., lyer P., Baranowitz S., Ellison Ch.J. 2011. Thermooxidative stabilization of polymers using natural and synthetic melanins. Macromolecules 44, 9499-9507.

Soares A.A., Souza C.G.M. de, Daniel F.M., Ferrari G.P., Costa S.M.G. da, Peralta R.M. 2009. Antioxidant activity and total phenolic content of Agaricus brasiliensis (Agaricus blazei Murril) in two stages of maturity. Food Chem. 112, 775-781.

Solano F. 2014. Melanins: skin pigments and much more - types, structural models, biological functions, and formation routes. New J. Sci. 2014, 28.

Soler-Rivas C., Arpin N., Olivier J.M., Wichers H.J. 1997. Activation of tyrosinase in Agaricus bisporus strains followin infection by Pseudomonas tolaasii with tolaasin-containing preparation. Mycol. Res. 101, 375-382.

Sun X., Wu B., Zhou L., Liu Z., Dong Y., Yang A. 2017. Isolation and characterization of melanin pigment from yesso scallop Patinopecten yessoensis. J. Ocean Univ. China 16(2), 279-284.

Suryanarayanan T., Ravishankar J., Venkatesan G., Murali T. 2004. Characterization of the melanin pigment of a cosmopolitan fungal endophyte. Myc. Res. 108(8), 974-978.

Vamos-Vigyazo L. 1981. Polyphenol oxidase and peroxidase in fruits and vegetables. Crit. Rev. Food Sci. Nutr. 15, 49-127.

Wang H., Pan Y., Tang X., Huang Z. 2006. Isolation and characterization of melanin from Osmanthus fragrans' seeds. LWT 39, 496-502.

Wang Q., Li B.B., Li H., Han J.R. 2010. Yield, dry matter and polysaccharides content of the mushroom Agaricus blazei produced on asparagus straw substrate. Sci. Hortic.125, 16-18.

Weijn A., Bastiaan-Net S., Wichers H.J., Mes J.J. 2013. Melanin biosynthesis pathway in Agaricus bisporus. Fungal Genet. Biol. 55, 42-53.

Xu C., Li J., Yang L., Shi F., Yang L., Ye M. 2017. Antibacterial activity and a membrane damage mechanism of Lachnum YM30 melanin against Vibrio parahaemolyticus and Staphylococcus aureus. Food Control 73, 1445-1451. 
Xu Y., Tian Y., Ma R., Liu Q., Zhang J. 2016. Effect of plasma activated water on the postharvest quality of button mushrooms, Agaricus bisporus. Food Chem. 197, 436-444.

Yao Z., Qi J., Wang L. 2012. Isolation, fractionation and characterization of melanin-like pigments from chestnut (Castanea mollissima) shells. J. Food Sci. 77(6), 671-676.

Ye M., Guo G., He Y., Lu Y., Ye Y., Yang Q., Yang P. 2012. Physiochemical characteristics and antioxidant activity of arginine-modified melanin from Lachnum YM-346. Food Chem. 135, 2490-2497.

Ye M., Wang Y., Qian M., Chen X., Hu X. 2011. Preparation and properties of the melanin from Lachnum singerianum. IJBAS-IJENS 11(3), 51-58.

Zhan F., He Y., Zu Y., Li T., Zhao Z. 2011. Characterisation of melanin isolated form a dark septate endpophyte (DSE), Exophiala pisciphila. World J. Microbiol. Biotechnol. 27, 2483-2489.

Zhang M., Xiao G., Thring R.W., Chen W., Zhou H., Yang H. 2015. Production and characterization of melanin by submerged culture of culinary and medicinal fungi Auricularia auricula. Appl. Biochem. Biotechnol. 176, 253-266.

Zhu H., He C-C., Chu Q-H. 2011. Inhibition of quorum sensing in Chromobacterium violaceum by pigments extracted from Auricularia auricular. Lett. Apll. Microbiol. 52, 269-274.

Zou Y., Wen Y., She W., Hu W. 2014. Physiochemical properties of melanin from A. auricula fruiting bodies. Adv. J. Food Sci. Technol. 6(8), 1002-1004.

Abstract. Natural melanins are of great potential value and application in the fields of pharmacology, cosmetics and functional foods. In the present study, natural melanin was reclaimed from waste after the harvesting of button mushroom (Agaricus bisporus). The physiochemical properties of raw and purified melanin were determined, including their ultraviolet-visible (UV-Vis), infrared (IR) and Raman spectra. Colour values, polyphenolic content, antioxidant and antibacterial activity were also evaluated. The result showed that the characteristics of the obtained pigments were similar to synthetic L-DOPA melanin. Raw and purified melanins showed differences in chemical composition, antioxidant activity and light barrier properties. Isolated melanins showed antibacterial activity against Enterococcus faecalis and Pseudomonas aeruginosa but were inactive against Bacillus cereus, Escherichia coli and Staphylococcus aureus. This is the first research on the character of melanin reclaimed from waste after the harvesting of $A$. bisporus. 
